\title{
Effect of induced polyploidy on plant growth, chlorophyll and flavonoid content of Artemisia cina
}

\author{
Sri Kasmiyati ${ }^{1}$, Elizabeth Betty Elok Kristiani ${ }^{1 *}$, Maria Marina Herawati ${ }^{2}$ \\ ${ }^{1}$ Faculty of Biology, Universitas Kristen Satya Wacana, Indonesia \\ ${ }^{2}$ Faculty of Agricultural and Bussines, Universitas Kristen Satya Wacana, Indonesia \\ *Email: betty.elok@uksw.edu
}

Submitted: 17 December 2019. Revised: 11 February 2020. Accepted: 20 March 2020

\begin{abstract}
Artemisia cina is one of a member of genus Artemisia that has potential as a medicinal plant. However, the levels of Artemisia medicinal bioactive compounds are very low. Polyploidization is an alternative method that can enhance of growth and secondary metabolite productions of plants. The aims of this research were to determine the effect of polyploid induction using colchicine and plant growth regulator toward plant growth, the chlorophyll, kaemferol and quercetin contents of $A$. cina. Four different $A$. cina used in this research consisted of two diploid genotypes (TWN and KJT) and two polyploid genotypes ( $\mathrm{J}$ and $\mathrm{M}$ ). Induction of mutant polyploid was conducted using colchicine and combination of plant growth regulator benziladenyl (BA) and 2,4-dichlorophenoxyacetic acid (2,4D). The measured plant growth parameters were dry weight, leaf area, and plant height. The chlorophyll content of leaves was determined spectrophotometrically, and flavonoid content determined using HPLC. The result showed that the polyploid genotype (M) significantly decreased leaf and root growth compared to the KJT and TWN. In A. cina plants, polyploidization using colchicine is more effective in increasing the biomass than using combination plant growth regulator BA and 2,4-D. The flavonoid content of KJT was the lowest, and significantly different compared to the other plants. This study provides new information about the effect of polyploid on growth and flavonoid content in A. cina. This can be useful information to develop A. cina to become a medicinal plant.
\end{abstract}

Key words: Artemisia cina, polyploid, colchicine, shoot culture, plant growth regulator

How to Cite: Kasmiyati, S., Kristiani, E. B. E., \& Herawati, M. M. (2020). Effect of induced polyploidy on plant growth, chlorophyll and flavonoid content of Artemisia cina. Biosaintifika: Journal of Biology \& Biology Education, 12 (1), 90-96

DOI: http://dx.doi.org/10.15294/biosaintifika.v12i1.22548

\section{INTRODUCTION}

Artemisia cina is a medicinal plant belongs to Compositae family that producing artemisinin as a major secondary metabolite compound. Artemisinin is used as antimalaria and effective against drugresistant malaria. Artemisinin and its derivatives also have the potential for the therapy of several infectious diseases such as leishmaniasis, hepatitis-B, and against cancer cell lines (Romero et al. 2005; Sen et al. 2007; Li et al. 2016). In addition to artemisinin, flavonoid such as quercetin and kaempferol compounds contained in A. cina is a secondary metabolite that is also potential for the development of herbal medicines. Kaempferol and quercetin have been reported to have several pharmacological properties as antimicrobial, anti-inflammatory, antioxidant, antitumor, cardioprotection, neuroprotection, antidiabetic, anti-hepatitis and also are being applied in cancer chemotherapy (Kelly, 2011; Cheng et al. 2015; Krishnadhas et al. 2016; Imran et al. 2019).

In general, plants naturally produce bioactive compounds in low concentrations. Biosynthesis of bioactive compounds is restricted to a single organ, such as leaves, roots, flowers or fruits, but accumulation and processing of the corresponding product can be detected in several other plant tissues
(Giri \& Lakshmi, 2000). The growth of plant organ and biosynthesis of many bioactive compounds is easily affected by environmental factors such as nutrient availability, stress factors, light, growth regulators and alteration ploidy (De Jesus, 2003). Artificial polyploidy is an alternative method that can enhance the vegetative and reproductive growth of plant organs and also plant biomass. The gene doses in the polyploid mutant were duplicated and will affect not only plant growth and biomass, but also plant activity enzymes, isozyme diversity, and responsible for improving secondary metabolite production (De Jesus, 2003; Kim et al. 2004). In the case of medicinal plant, polyploid is more helpful and affordable due to the enhanced biomass and biosynthesis of bioactive compounds (Salma et al. 2017). The enhancement of plant biomass and the secondary metabolite productions via induced polyploidy has been reported by several researchers. Corneillie et al. (2019) reported that in Arabidopsis polyploid mutants, the dry weight of the stem was doubled and saccharification yield was significantly increased. The polyploid adventitious roots play a role in enhancing the production of ginsenoside and biomass in Panax ginseng (Kim et al. 2004). The induced polyploid medicinal orchid (Anoectochilus formosanus) was reported significantly enhance on 
various growth parameters including dry weight, fresh weight, shoot length, root length, leaf width, the size of the stoma, and the number of chloroplasts per stoma. The tetraploid medicinal orchid plants also produced significantly higher contents of total flavonoid and gastrodin than the diploid plants (Chung et al. 2017).

The genetic improvement of Artemisia through artificial polyploidization has been done on the $A$. аппиа plant by several researchers. De Jesus (2003) reported that tetraploid clones of A. апnиa resulting from colchicine-treated hairy root culture showed major differences in growth and development and yield artemisinin 2-5 times higher than diploid clones. Banyai et al (2010) reported that Artemisia annua were successfully induced to be tetraploid plants by treating leaves tissue culture with $0.1 \%$ colchicine. The tetraploid of A. аnnua plants showed larger sizes of the root system, stomata, and glandular secretory trichomes and yield artemisinin 1.5 times, whereas leaf size in tetraploid was smaller but thicker than diploid plant. Polyploid plantlet of $A$. аnnua was also reported to have a bigger size of stomata and produced more artemisinin than diploid plantlet (Rahman et al. 2016). A. cina is another species member of genus Artemisia that also has potential as a medicinal plant and source of bioactive compound (anticancer, antibacterial and antifungal). Moreover, the effect of polyploidization on shoot culture of $A$. cina using plant growth regulator treatment toward plant growth has also been reported by Herawati et al. (2015).

The aims of this research were to determine the effect of induced polyploidization using colchicine and plant growth regulator toward plant growth, the chlorophyll and content of quercetin and kaempferol on A. cina. This research was expected to provide additional information that reinforces the importance of polyploidization in enhancing the growth and production of bioactive compounds of medicinal plants, especially A. cina.

\section{METHODS}

The research was conducted using a Completely Randomized Design. The four genotypes of A. cina were used in this research. The two diploid genotypes of A. cina namely TWN and KJT were obtained from The Center for Research and Development of Medicinal Plants and Traditional Medicine (B2P2TOOT), Tawangmangu, Central Java, Indonesia. KJT genotypes were the diploid plants of $A$. cina that were obtained through shoot culture. While TWN genotype was harvested directly from the plantation land The plants were identified at the Herbarium Bogoriense, Biology Research Center, Bogor, Indo- nesia. Polyploid genotypes $\mathrm{J}$ and $\mathrm{M}$ were considered as mutant polyploid putative $1(\mathrm{P} 1)$.

\section{Propagation of Explants}

The medium for shoot culture was MS medium containing $10 \mathrm{mg} \mathrm{L}-1$ of kinetin and $1 \mathrm{mg} \mathrm{L}-1$ of NAA (1-Napthalaeneacetic acid). The shoot explants used were from in vitro culture. Each shoot explants had consisted of three stem segments. The segments from two until six were planted in MS medium containing $10 \mathrm{mg} \mathrm{L}-1$ of kinetin and $1 \mathrm{mg} \mathrm{L}-1$ of NAA. Every four weeks, the explants were sub-cultured by cutting off three stem segments and replanting them in the new MS medium like before.

\section{Induction of Polyploidy}

Colchicine at the concentration of $100 \mathrm{mg} / \mathrm{l}$ was used to induce $\mathrm{J}$ mutant polyploid and combination of $2 \mathrm{mg} / \mathrm{ml}$ of BA (Benziladenyl) and $3 \mathrm{mg} / \mathrm{ml}$ of $2,4 \mathrm{D}$ was to induce $\mathrm{M}$ mutant polyploid of $A$. cina. In the first step, the identical explants were selected. The transfer of explants to polyploid induction media was done two weeks after the final propagation subculture stage followed by incubation until the plantlet formed.

\section{Acclimatization of Plantlet}

The plantlets of $A$. cina were transferred into plastic pots containing husk charcoal as a medium, then they were incubated at room temperature for 14 days. The plantlets were fertilized using $2 \mathrm{ml}$ of NPK liquid fertilizer. At the end of the incubation period, the plantlets were transferred to the glasshouse for 14 days. After that process, the plantlet was transferred into a $20 \mathrm{~cm}$ diameter polybag with a mixture of garden soil medium and manure $(1: 1)$.

\section{Determination of Shoot and Root Dry Weight}

The plant growth were determined at the end of the acclimatization period through its shoot and root dry weights. The shoots were harvested at the soil surface level, and the roots were dried without direct sunlight until they wither. Drying the shoots and roots was conducted by heating in a $40^{\circ} \mathrm{C}$ oven until it reached a constant weight.

\section{Determination of Leaf Area}

The leaf area was measured using Leaf Area Meter Mark 2 type (Delta T, Burwell Cambridge, England). The leaves measured were the completely unfolded leaf and in the 3, 5, 8 and 10 sections.

\section{Determination of Chlorophyll Content}

The chlorophyll content of leaves was determined using Dimethyl sulfoxide (DMSO) as a solvent. The sample used was the third segment with completely 
unfolded leaves. As much as 0.04 grams of leaves were sliced into small pieces and added with $5 \mathrm{~mL}$ DMSO and incubated in the dark at room temperature for 48 hours. At the end of incubation, the mixtures were filtered with filter paper. The absorbance of the mixture was measured using a spectrophotometer (UV mini-1240, UV VIS Spectrophotometer, Shimadzu) at a wavelength of 649 and $665 \mathrm{~nm}$. The chlorophyll content was calculated using the following equation:

Chlorophyll a $=(12: 19 \times$ A665) $-(3: 45 \times$ A649 $)$

$\mu \mathrm{g} / \mathrm{mL}$

Chlorophyll b $=(21.99 \times$ A649 $)-(5: 32 \times$ A665 $)$

$\mu \mathrm{g} / \mathrm{mL}$

Total Chlorophyll $=(18: 54 \times$ A649 $)+(6.87 \times$ A665 $)$ $\mu \mathrm{g} / \mathrm{mL}$

\section{Determination of Flavonoid Content}

The flavonoid content (kaempferol and quercetin) was analyzed using High-Performance Liquid Chromatography (HPLC) (Tokusoglu et al. 2003). For separation of quercetin and kaempferol, the HPLC conditions were using the Chromosorb Column RP $\mathrm{C} 18$ (150 x $5 \mathrm{~mm}$ id - KNAUER), $\mathrm{H}_{3} \mathrm{PO}_{4} 0.1 \%$ : acetonitrile (60:40) as the mobile phase, the flow rate $1 \mathrm{ml} / \mathrm{min}$, the injection volume of $20 \mu \mathrm{l}$, ambient temperature, and using UV $370 \mathrm{~nm}$ detector. The quantitation of the amounts of the quercetin and kaempferol in A. cina sample extracts were determined by using a standard curve of quercetin and kaempferol pure compounds calibration .

\section{Data analysis}

The analysis data were conducted statistically using a one-way analysis of variance (ANOVA) to evaluate differences among all genotypes in plant growth and content of chlorophyll and flavonoid. Mean separation was performed using the Tukey test with a $\mathrm{P} \leq 0.05$ probability level.

\section{RESULTS AND DISCUSSION}

The organ growth (root dry weight, shoot dry weight and leaf area) of the four tested A. cina genotypes, did not show totally significant difference between diploid (KJT and TWN genotypes) and polyploid (J genotype), except for mutant polyploid genotype (M) (Table 1). The root and shoot dry weight of $\mathbf{J}$ was higher than the KJT and TWN. The leaf and root growth of $\mathrm{M}$ genotype (polyploid) experienced a significant decrease, shown by having the lowest growth in terms of root dry weight, shoot dry weight and leaf area compared to three others (KJT, TWN and J genotypes). The highest dry weight of roots and shoots was found in $\mathrm{J}$, while the highest leaf area was found in KJT.
Table 1. The growth of the diploid (KJT and TWN) and polyploid mutant ( $\mathrm{J}$ and $\mathrm{M}$ ) of A. cina

\begin{tabular}{lllll}
\hline Genotype & $\begin{array}{l}\text { Level } \\
\text { of } \\
\text { ploidy }\end{array}$ & $\begin{array}{l}\text { Root dry } \\
\text { weight } \\
(\mathrm{g})\end{array}$ & $\begin{array}{l}\text { Shoot } \\
\text { dry } \\
\text { weight } \\
(\mathrm{g})\end{array}$ & $\begin{array}{l}\text { Leaf } \\
\text { area } \\
(\mathrm{cm} 2)\end{array}$ \\
\hline \multirow{2}{*}{$\mathrm{KJT}$} & \multirow{2}{*}{$2 \mathrm{x}=2 \mathrm{n}$} & $\begin{array}{l}12.63 \pm \\
1.19 \mathrm{ab}\end{array}$ & $\begin{array}{l}9.21 \pm \\
0.83 \mathrm{~b}\end{array}$ & $\begin{array}{l}33.55 \pm \\
0.71 \mathrm{a}\end{array}$ \\
\hline \multirow{2}{*}{$\mathrm{TWN}$} & \multirow{2}{*}{$2 \mathrm{x}=2 \mathrm{n}$} & $\begin{array}{l}14.48 \pm \\
2.64 \mathrm{a}\end{array}$ & $\begin{array}{l}10.49 \pm \\
0.12 \mathrm{~b}\end{array}$ & $\begin{array}{l}32.87 \pm \\
0.84 \mathrm{a}\end{array}$ \\
\hline \multirow{2}{*}{$\mathrm{J}$} & \multirow{2}{*}{$2 \mathrm{x}=4 \mathrm{n}$} & $\begin{array}{l}16.84 \pm \\
3.97 \mathrm{a}\end{array}$ & $\begin{array}{ll}13.07 \pm \\
0.51 \mathrm{a}\end{array}$ & $\begin{array}{l}33.27 \pm \\
1.39 \mathrm{a}\end{array}$ \\
\hline \multirow{2}{*}{$\mathrm{M}$} & \multirow{2}{*}{$2 \mathrm{x}=4 \mathrm{n}$} & $\begin{array}{l}6.94 \pm \\
1.30 \mathrm{~b}\end{array}$ & $\begin{array}{l}7.22 \pm \\
0.72 \mathrm{c}\end{array}$ & $\begin{array}{l}29.93 \pm \\
\end{array}$ \\
\end{tabular}

Results are the mean \pm standard deviation (SD) of three replications. Values with the same letter in a column are not significantly different $(p>0.05)$.

Table 1 also shows that colchicine mutagen was more able to increase leaf and root growth compared to the combination of the plant growth regulator of BA and 2,4-D. Artificial polyploid induction in $A$. cina plants using different mutagens shows different growth responses, as seen in leaf growth (Figure 1). Ade and Rai (2010) reported that colchicine has the ability to induce polyploidy and can be used to convert sterile hybrids into fertile. The colchicine mutagen has been shown to induce polyploidy in various plants, including Scutellaria baicalensis (Gao et al. 2002), Panax ginseng (Kim et al. 2004), Artemisia annua (De Jesus, 2003; Banyai et al. 2010; Rahman et al. 2010) 2017), Codonopsis lanceolata (Kwon et al. 2016), Glycyrrhiza glabra var. glandulifera (Bernard et al. 2012), and Artemisia cina (Herawati et al. 2015).

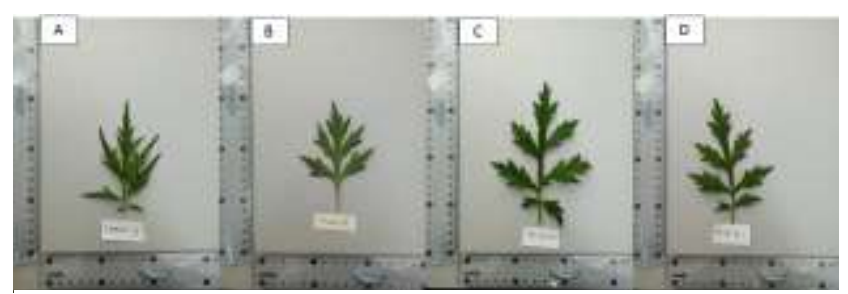

Figure 1. The different leaves growth of the four genotypes of A. cina plants. (A) KJT, (B) TWN, (C) $\mathrm{J}$ and (D) $\mathrm{M}$.

Although colchicine treatment in this study can induce polyploidy in A. cina and also increase leaf and root growth, the results are not significant. This can be caused by several factors. The effect of colchicine in polyploidization is different regarding its concentration, method, duration of treatment, and also genetic factors of the treated plants (Aina et al. 2012; Dhooghe et al. 2011; Moghbel et al. 2015). When compared to colchicine, the combination of BA and 
2,4-D had no significant effect on the formation of $A$. cina polyploid mutants. In general, the combination of BA and 2,4-D plays a role in stimulating the formation of callus and plantlets in some plants including soybeans (Kristanti et al., 2013), gendarussa (Wahyuni et al., 2017), and pineapple (Zulkarnain et al., 2018).

The growth of diploid and polyploid of A. cina is also determined based on plant dry weight (Figure 2A) and plant height (Figure 2B). The plant dry weight of the two diploid plants was not significantly different either the plant that was directly harvested from the land (TWN) or the one obtained from shoot culture (KJT). Differ from the diploid plants, the plant dry weight of the two polyploidy plants were significantly different from each other. The plant weight of $\mathbf{J}$ was higher $(29.91 \pm 4.46 \mathrm{~g})$ than the $\mathrm{M}$ $(14.16 \pm 2.02 \mathrm{~g})$. The plant height was significantly different among four tested A. cina genotypes. In this study, artificial polyploidization using mutagen both in the form of colchicine and a combination of plant growth regulators (BA and 2,4D) on $A$. cina reduced plant height compared to diploid plants (wild type). The lowest plant height was found in genotype $\mathrm{M}$ polyploid mutants at $33.13 \pm 1.00 \mathrm{~cm}$, and the highest plant height was found in wild type plant (TWN genotype) at $58.67 \pm 0.61 \mathrm{~cm}$.

A.

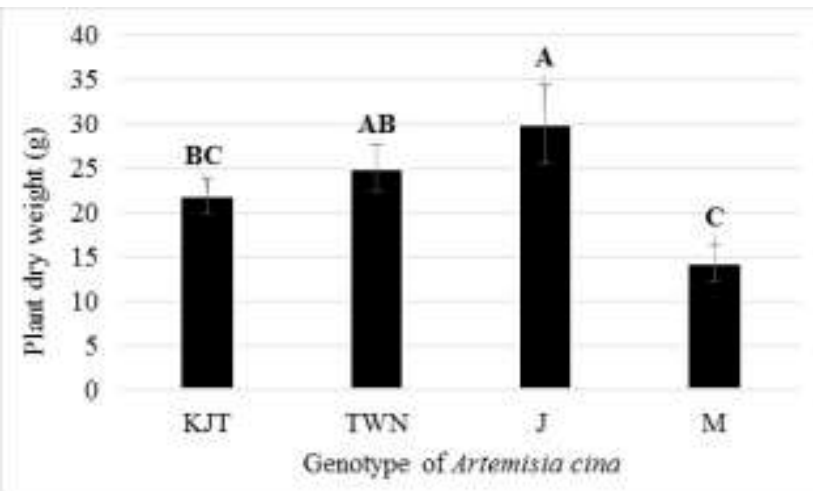

B.

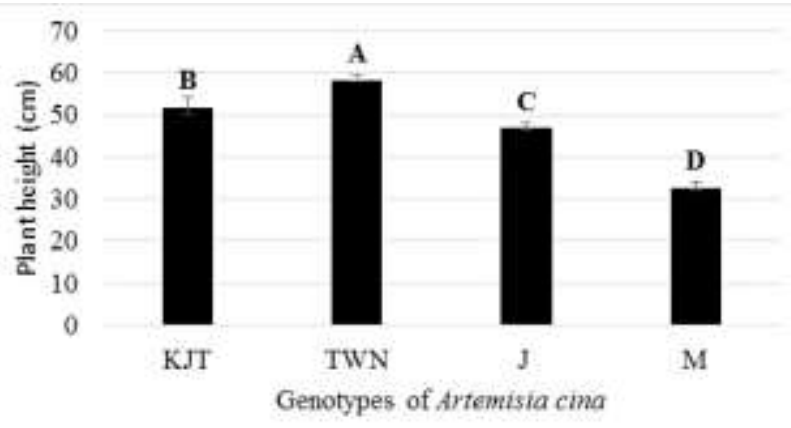

Figure 2. The plant dry weight (A) and plant height (B) of the diploid plant (KJT and TWN) and polyploid mutant of $A$. cina $(\mathrm{J}$ and $\mathrm{M})$.
The increased plant growth due to polyploidization has been also reported by many researchers. A twofold increase in stem dry weight in Arabidopsis polyploid mutants compared to the wild type was reported by Corneillie et al. (2019). The increased ginseng plant biomass due to polyploid induction was also reported by Kim et al. (2004). The induced polyploid medicinal orchid (Anoectochilus formosanus) was also reported significantly enhanced on various growth parameters including dry weight, fresh weight, shoot length, root length, and leaf width (Chung et al. 2017). However, the decrease in plant height shown on polyploid A. cina plants in this study was related to duplicated gene doses in polyploid mutants that would affect not only growth but also enzyme activity. The slow and stunted growth of A. cina polyploid mutant was one of the successful indicators of polyploidy induction. The decrease in plant height of A. cina polyploid may be due to physio-chemical disturbance of cell and induction of polyploidy (Mazoor et al. 2018).

Artificial polyploid induction significantly affects the total chlorophyll content in A. cina (Figure 3). The total chlorophyll content of polyploid plants ( $\mathrm{J}$ and $\mathrm{M})$ is lower than diploid plants (KJT and TWN). However, among of the diploid plants and mutant polyploid plants, the chlorophyll content were not significantly different from each other. The chlorophyll content of KJT, TWN, J and M genotypes of A. cina respectively are as follow, $3.00 \pm 0.10,2.85$ $\pm 0.17,2.16 \pm 0.08$, and $2.25 \pm 0.06 \mu \mathrm{g} / \mathrm{ml}$. The reduction in total chlorophyll content of the A. cina polyploid mutant in this study is not in line with the results of studies reported by several previous researchers. Polyploid induction is reported to increase chlorophyll content in some plants including Acacia mearnsii (Mathura et al. 2006), Pogostemon cablin (Wu \& Li, 2013), Stevia reboudiana (Zhang et al. 2018) and Artemisia annua (Yunus et al. 2018). However, Manzoor et al. (2018) reported that colchicine-induced polyploid in Gladiolus grandiflorus was decreased the chlorophyll content, this result supports the result of this study. According to $\mathrm{Xu}$ et al. (2010), the reducing of total chlorophyll content in induced tetraploid plants occurred due to structural modifications such as disintegration in the lamellar or thylakoid membrane of chloroplast which affect the synthesis of chlorophyll.

Polyploidy is considered a method of increasing bioactive compound potential in plants. In this study, the effect of induced polyploidization using colchicine and a combination of plant growth regulators (BA and 2,4-D) on the content of flavonoids in the form of quercetin and kaemferol compounds in $A$. cina was also determined. 


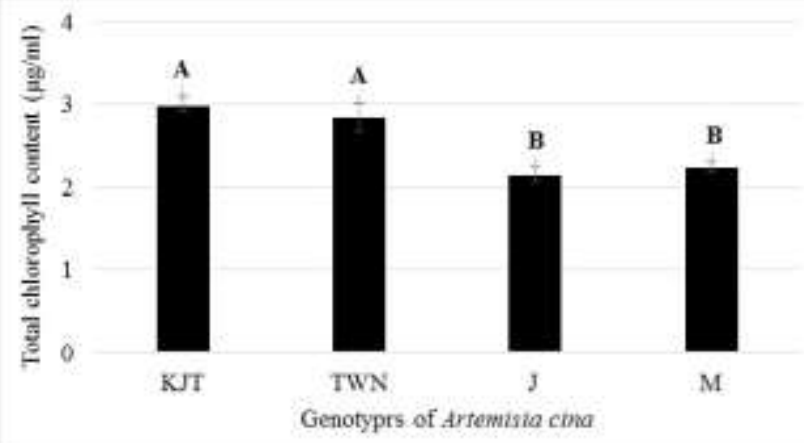

Figure 3. The total chlorophyll content of the diploid plant (KJT and TWN) and polyploid mutant ( $\mathrm{J}$ and M) of A. cina

The results showed that induced polyploid in $A$. cina significantly increased quercetin and kaemferol contents. The quercetin and kaempferol content of KJT shows the lowest value, and significantly different from another diploid plant (TWN) and polyploid plants ( $\mathrm{J}$ and $\mathrm{M}$ ) (Figure 4). The content of quercetin among the TWN, $J$ and $M$ was not significantly different. The kaempferol content of $\mathrm{KJT}$, TWN, $\mathrm{J}$ and $\mathrm{M}$ were $3.61 \pm 0.01,4.92 \pm 0.05$, $5.33 \pm 0.54$, and $4.97 \pm 0.13 \mu \mathrm{g} / \mathrm{ml}$, respectively (Figure 4A). The lowest quercetin content was found in KJT by $39.81 \pm 0.41 \mu \mathrm{g} / \mathrm{ml}$, and the highest was found in M by $52.92 \pm 1.09 \mu \mathrm{g} / \mathrm{ml}$ (Figure 4B).

A.

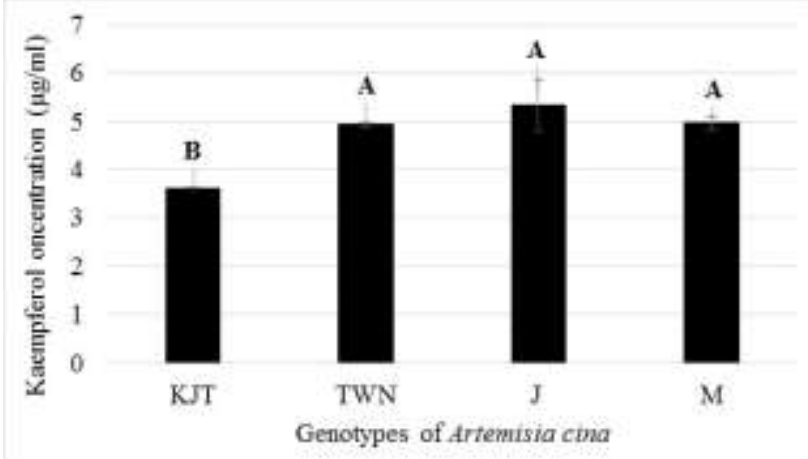

B.

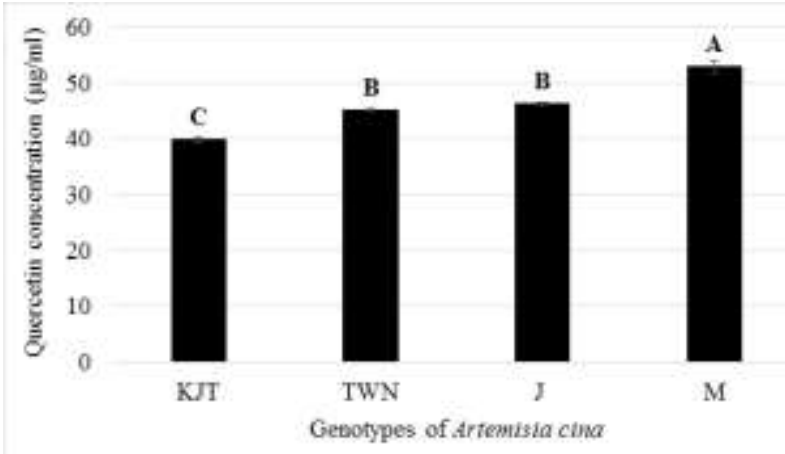

Figure 4. The kaempferol (A) and quercetin (B) contents of the diploid plants (KJT and TWN genotypes) and polyploid mutants ( $\mathrm{J}$ and $\mathrm{M}$ genotypes) of A. cina
The increase in flavonoid content (quercetin and kaemferol) in induced polyploid A. cina in this study is supported by Chung et al. (2017) who also reported an increase in flavonoid content in the medicinal orchid plant (Anoectochilus formosanus). According to Parida and Mishra (2015), polyploidization can induce changes in the quality and quantity of secondary metabolites such as phenols, terpenoid, anthocyanin, and flavonoid, and higher ploidy levels are clearly reflected in higher accumulation of flavonoids in plants. Some induced polyploidy plants are reported to produce more flavonoids or terpenoids than diploid wild types, including in Artemisia annиa (De Jesus, 2003) and Scutellaria baicalensis (Gao et al. 2002). According to Salma et al. (2017), polyploid plays a major role and is more prospective than diploid in the development of medicinal plants because the increase in the number of alleles in polyploid can mask lethal recessive mutations, the formation of heterosis (allopolyploid and autopolyploid) which can confer transgressive performance and hybrid vigor, the doubling of alleles might be the cause of various new functions to increase resistance to various diseases and environmental changes.

The research on artificial polyploidization to increase the biomass and content of artemisinin and other secondary metabolites has been carried out in member of Artemisia, but it has not been much studied on A. cina. The finding of appropriate and effective methods to induce polyploid and increase flavonoid content in A. cina through this research is important to support the development of A. cina as one of the potential medicinal plants.

\section{CONCLUSION}

The growth of organ, biomass and chlorophyll content of A. cina not totally significantly different between polyploid and diploid plants. The polyploid genotype (M) significantly decreased leaf and root growth compared to the KJT and TWN. The induced polyploid in A. cina significantly increased quercetin and kaemferol contents compared to diploid plants. Colchicine is the most effective to induce polyploidy in A. cina. Colchicine mutagen shows higher leaf and root growth compared to the combination of the plant growth regulator of BA and 2,4-D.

\section{ACKNOWLEDGMENTS}

This research and publication are funded by the Ministry of Research, Technology and Higher Education of the Republic of Indonesia through the Penelitian Dasar Unggulan Perguruan Tinggi 
(PDUPT) Scheme Desentralisasi Program in 2019. The authors are greatly thankful for the funder.

\section{REFERENCES}

Ade, R. \& Rai, M.K. (2010). Review: colchicine, current advances and future prospects. Bioscience. 2, 90-96.

Aina, O., Quesenberry, K., \& Gallo, M. (2012). In vitro induction of tetraploids in Arachis paraguariensis. Plant Cell Tiss. Org, 111(2), 231-238.

Banyai, W., Sangthong, R., Karaket, N., Inthima, P., Mii, M., \& Supaibulwatana, K. (2010). Overproduction of artemisinin in tetraploid Artemisia annua L. Plant Biotechnology. 27, 427-433.

Bernard, F., Moghbel, N., \& Hassannejad, S. (2012). Treatment of licorice seeds with colchicine: changes in seedling DNA levels and anthocyanin and glycyrrhizic acid contents of derived callus cultures. Natural Product Communications. 7(11), 1457-1460.

Cheng, Z., Sun, G., Guo, W., Huang, Y., Sun, W., Zhao, F., \& Hu, K. (2015). Inhibition of hepatitis $\mathrm{B}$ virus replication by quercetin in human hepatoma cell lines. Virologica Sinica. 30(4), 261-268.

Chung, H., Shi, S., Huang, B., \& Chen, J. (2017). Enhanced agronomic traits and medicinal constituents of autotetraploids in Anoectochilus formosanus Hayata, a top-grade medicinal orchid. Molecules. 22, 1-13.

Corneillie, S., Storme, N.D., Acker, R.V., Fangel, J.U., Bruyne, M.D., Rycke, R.D., Geelen, D., Willats, W.G.T., Vanholme, B., \& Boerjan, W. (2019). Polyploidy affects plant growth and alters cell wall composition. Plant Physiology. 179, 7487.

Dhooghe, E., Van Laere, K., Eeckhaut, T., Leus, L., \& Van Huylenbroeck, J. (2011). Mitotic chromosome doubling of plant tissues in vitro. Plant Cell Tiss. Org. 104(3), 359-373.

De Jesus, L. (2003). Effect of Artificial Polyploidy in Transformed Roots of Artemisia annua L (Master Thesis). Worcester Polytechnic Institute, City, State.

Giri, A., \& Lakshmi-Narasu, M. (2000). Transgenic hairy roots: recent trends and applications. Biotechnol. Adv. 18, 1-22.

Gao, S.L., Chen, B.J., \& Zhu, D.N. (2002). In vitro production and identification of autotetraploids of Scutellaria baicalensis. Plant Cell, Tissue and Organ Culture. 70, 289-293.

Herawati, M.M., Pudjihartati, E., Pramono, S., Sulistyaningsih, E., \& Purwantoro, A. (2015) Obtaining Artemisia cina polyploid through plant growth regulator treatment in shoot culture. Agrivita. 37, 178-184.
Imran, M., Salehi, B., Sharifi-Rad, J., Gondal, T.A., Saeed, F., Imran, A., Shahbaz, M., Fokou, P.V.T., Arshad, M.U., Khan, H., Cguerreiro, S.G., Martins, N., \& Esrevinho, L.M. (2019). Review: kaempferol a key emphasis to its anticancer potential. Molecules. 24, 1-16.

Kelly, G.S. (2011). Quercetin: alternative medicine review. Monograph. The Official Journal of The American College for Advancement in Medicine. 16(2), 172-194.

Kim, Y., Hahn, E., Murthy, H.N., \& Paek, K. (2004). Effect of polyploidy induction on biomass and ginsenoside accumulations in adventitious roots of ginseng. Journal of Plant Biology. 47(4), 356-360.

Krishnadhas, Santhi, R., \& Annapurani, S. (2016). Isolation and identification of flavonoid fractions from the leaves of Volkameria inermis and its invitro cytotoxic study. International Journal of Pharmaceutical and Clinical Research. 8(12), 1648-1653.

Kristanti, I., N. A. Habibah \& L. Herlina. (2013). Optimization of 2,4-D concentration, BA, and long irradiation to promote regeneration buds from callus of soybean. Biosaintifika: Journal of Biology \& Biology Education. 5(1), 50-57

Kwon, S., Seo, D., Cho, G., Lee, M., Moon, Y., Boo, H., Woo, S., \& Kim, H. (2016). Effect of colchicine on chromosome doubling in Codonopsis lanceolata. Korean J. Plant Res. 29(3), 347-354.

Li, Z., Li, Q., Wu, J., Wang, M., \& Yu, J. (2016). Review: artemisinin and its derivatives as a repurposing anticancer agent: What else do we need to do?. Molecules. 21, 1-14.

Mazoor, A., Ahmad, T., Bashir, M.A., Baiq, M.M.Q., Quresh, A.A., Shah, M.K.N., \& Hafiz, I.A. (2018). Induction and identification of colchicine induced polyploidy in Gladiolus grandiflorus 'White Prosperity'. Folia Horticulturae. 30(2), 307-319.

Mathura, S., Fossey, A., \& Beck, S.L. (2006). Comparative study of chlorophyll content in diploid and tetraploid black wattle (Acacia mearnsii). Forestry. 79(4), 382-388.

Moghbel, N., Borujeni, M.K. , \& Bernard, F. (2015). Colchicine effect on the DNA content and stomata size of Glycyrrhiza glabra var. glandulifera and Carthamus tinctorius L. cultured in vitro. J. Gen. Eng. Biotechnol. 13(1), 1-6.

Parida, B.P. \& Mishra, B.B. (2015). Is a plant's ploidy status reflected in its metabolome?. Journal of Postdoctoral Research. 3(4), 1-11.

Rahman, W., Hafiizh, E.A., Ermayanti, T.M., Rantau, D.E., \& Lelono, A.A. (2017). Acclimation and agronomic performance of polyploids clones of $A r$ temisia annua L. Jurnal Biologi Indonesia. 13(1), 33-41. 
Romero, M.R., Efferth, T., Serrano, M.A., Castano, B., Macias, R.I., \& Marin, J.J. (2005). Effect of artemisinin/artesunate as inhibitors of hepatitis B virus production in an "in vitro" replicative system. Antiviral Res. 66(2), 75-83.

Salma, U., Kundhu, S., \& Mandal, N. (2017). Artificial polyploidy in medicinal plants: advancement in the last two decades and impending prospects. J. Crop Sci. Biotech. 20(1), 9-19.

Sen, R., Bandyopadhyay, S., Duta, A., Mandal, G., Ganguly, S., Saha, P., \& Chatterjee, M. (2007). Artemisinin triggers induction of cell-cycle arrest and apoptosis in Leishmania donovani promastigotes. J. Med. Microbiol. 56(Pt 9), 12131218.

Tokusoglu, O., Unal, M.K., \& Yildirim, Z. (2003). HPLC-UV and GC-MS characterization of the flavonol aglycons quercetin, kaempferol, and myricetin in tomato pastes and other tomato-based products. Acta Chromatographica. 13, 196-207.

Wahyuni, D. K., P. Andriani, A. N. M. Ansori \& E. S. W. Utami. (2017). Callus induction of gendarussa (Justicia gendarussa) by various concentration of
2,4-D, IBA, and BAP. Biosaintifika: Journal of Biology \& Biology Education. 9(3), 402-408.

Wu, Y. \& Li, M. (2013). Induction of tetraploid plants of Pogostemon cablin (Blanco) and its quality evaluation. Pharmacognosy Journal. 5, 281285

Xu L., Najeeb U., Naeem M.S., Daud M.K., Cao J.S., Gong H.J., Shen, W.Q. \& Zhou, W.J. (2010). Induction of tetraploidy in Juncus effusus by colchicine. Biol. Plantarum. 54(4), 659-663.

Yunus, A., Parjanto, Samanhudi, Hikam, M.P., \& Widyastuti, Y. (2018). Polyploid response of $A r-$ temisia annua L. to colchicine treatment. IOP Conf. Series: Earth and Environmental Science. 142.

Zhang, H., An, S., Hu, J., Lin, Z., Liu, X., Bao, H., \& Chen, R. (2018). Induction, identification and characterization of polyploidy in Stevia rebaudiana Bertoni. Plant Biotechnology. 35, 81-86

Zulkarnain, Neliyati, \& Eliyanti. (2018). Plantlets regeneration from crown bud slicing of pineapple (Ananas comosus). Biosaintifika: Journal of Biology \& Biology Education. 10(3), 484-490. 